\title{
REPRESENTASI KESALAHAN KOMUNIKASI TULIS DALAM MENYELESAIKAN SOAL INDUKSI MATEMATIKA
}

\author{
Nursupiamin $^{1}$; Agung Wicaksono \\ ${ }^{1,2}$ Program Studi Tadris Matematika, FTIK, Institut Agama Islam Negeri Palu \\ ${ }^{1}$ nursupiamin@iainpalu.ac.id
}

\begin{abstract}
Abstrak: Dalam merepresentasi kesalahan komunikasi tulis dalam menyelesaikan soal induksi matematika, peneliti menggunakan pendekatan deskriptif kualitatif dengan subjek penelitian berjumlah 20 orang yang merupakan mahasiswa Tadris Matematika FTIK IAIN Palu yang memprogram Mata Kuliah Teori Bilangan. Teknik pengumpulan data yang digunakan adalah dengan pemberian tes induksi matematika. Hasil kajian menunjukkan kesalahan komunikasi tulis pada aspek ketepatan dan kebenaran jawaban sebesar $37.95 \%$, aspek penggunaan bahasa matematika sebesar $30.12 \%$, aspek struktur jawaban sebesar $17.47 \%$ dan aspek strategi pemecahan yang digunakan sebesar $14.46 \%$. Pada kajian ini, kesalahan pada aspek penggunaan bahasa matematika cenderung berdampak pada aspek ketepatan dan kebenaran jawaban yang disebabkan kurangnya penguasaan konsep induksi matematika dan lemahnya penguasaan pembuktian mengikuti prosedur.
\end{abstract}

Kata Kunci : Kesalahan, Komunikasi Tulis, Induksi Matematika

Komunikasi berperan penting dalam kehidupan manusia khususnya ketika mengumpulkan berbagai informasi yang ingin diketahui. Aktivitas berkomunikasi dalam pembelajaran yang melibatkan peserta didik dan pendidik, perlu dikembangkan karena terjadi pertukaran dan penyampaian materi serta aktivitas berelasi (Nursupiamin, 2020). Bagi peserta didik, komunikasi yang aktif memiliki kontribusi dalam kemampuan menyajikan ide dan strategi penyelesaian secara jelas (Maulyda et al., 2020). Terkait pembelajaran matematika, Baroody (dalam Saptika dkk) menegaskan bahwa pembelajaran yang baik mampu membimbing peserta didik dalam menyampaikan ide matematika melalui aspek representing, listening, reading, discussing dan writing (Saptika et al., 2018). Penyampaian ide matematika atau komunikasi matematis ditunjukkan melalui penyampaian gagasan matematika secara lisan dan tertulis (Hodiyanto, 2017). Komunikasi secara lisan ditunjukkan melalui penyampaian ungkapan melalui penjelasan secara verbal, sedangkan komunikasi tertulis terlihat secara fisik dalam bentuk tulisan, kata-kata, gambar, tabel, dan lainnya (Amelia \& Trismawati, 2015).

Pada kajian ini, peneliti hanya memandang variabel komunikasi tertulis dengan indikator merujuk pada rubrik penilaian komunikasi tertulis oleh Firda dkk yaitu mencakup aspek penggunaan bahasa matematika, strategi pemecahan yang digunakan, ketepatan dan kebenaran jawaban, serta struktur jawaban (Firda et al., 2019). Kemampuan komunikasi tertulis bukanlah hal yang mudah untuk dikuasai peserta didik. Secara umum, peserta didik mengalami kesalahan dalam menyampaikan ide secara tertulis yang dapat disebabkan berbagai faktor, yaitu kurangnya pengetahuan, pengembangan gagasan dan rendahnya kebiasaan membaca (Fannies, 2016). Anggapan lain tentang faktor penyebab kesalahan yang dikemukakan oleh Ardiawan adalah mahasiswa kurang menguasai konsep-konsep sehingga konsepsi peserta didik berbeda 
dengan konsepsi pendidik (Ardiawan, 2015). Faktor lain yang dapat menyebabkan peserta didik mengalami kesalahan dalam menyelesaikan soal adalah tidak bisa menjawab sesuai pertanyaan sehingga mengalami kesulitan untuk mengerjakan soal tersebut (Saptika et al., 2018).

Salah satu topik pada mata kuliah matematika yang menuntut peserta didik berlatih berkomunikasi tulis adalah mata kuliah teori bilangan. Dalam mata kuliah ini, materi induksi matematika yang merupakan materi awal terkait teknik atau metode pembuktian dasar dalam matematika yang harus dipahami oleh peserta didik sejak awal karena menjadi prasyarat dalam prinsip pembuktian yang digunakan pada mata kuliah matematika selanjutnya. Pada induksi matematika, pembuktian memuat langkah basis (dasar) induksi, hipotesis induksi dan langkah induksi. Adapun prosedur pembuktian dengan menggunakan prinsip induksi matematis yaitu:

Misalkan $\mathrm{P}(\mathrm{n})$ suatu pernyataan matematika yang berkorespondensi pada himpunan bilangan asli, maka dalam langkah basis (dasar) induksi dibuktikan bahwa untuk $\mathrm{n}=1$ berlaku P(1). Selanjutnya pada sebelum menempuh langkah induksi terlebih dahulu diasumsikan hipotesis induksi berlaku. Artinya andaikan $\mathrm{P}(\mathrm{k})$ benar untuk $\mathrm{n}=\mathrm{k}$, maka akan dibuktikan langkah induksi yaitu membuktikan $\mathrm{P}(\mathrm{k}+1)$ benar untuk $\mathrm{k}>\mathrm{n}$ (Huda et al., 2018).

Induksi matematika merupakan salah satu teknik pembuktian yang sangat penting. Ide dari prinsip induksi matematika ini diilustrasikan dari efek sekuensial dari domino yang jatuh. Efek ini diakibatkan adanya efek pada susunan atau deretan domino yang secara tegak dengan jarak yang agak dekat dan memiliki jarak yang sama. Jika domino pertama dijatuhkan maka akan mengakibatkan domino berikutnya ikut jatuh.

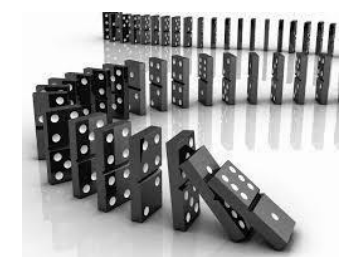

\section{Gambar 1: Efek Domino (Sumber: google.com)}

Huda dkk memaparkan bahwa peserta didik di tingkat sekolah menengah memiliki ketertarikan yang kurang untuk mendalami induksi matematika. Hal ini didasarkan induksi matematika tidak termuat dalam soal ujian (Huda et al., 2018). Ketidaktertarikan terhadap materi akan berdampak ketika peserta didik dihadapkan dengan topik pembuktian secara deduktif khususnya dengan menggunakan prinsip induksi matematika. Kelemahan dalam membuktikan suatu pernyataan dapat terdeteksi melalui kesalahan atau kesulitan yang dialami peserta didik dalam mengerjakan soal. Peserta didik yang mengalami kesulitan dalam menyampaikan suatu ide namun pendidik memahaminya, maka pada kondisi tersebut pendidik dipandang mampu mendeteksi kesalahan yang dialami peserta didik (Maulyda et al., 2020).

Dengan memperhatikan paparan tersebut, maka penting dilakukan representasi kesalahan komunikasi tulis dalam menyelesaikan soal induksi matematika. Kajian ini dianggap bermanfaat bagi pendidik mengetahui akar permasalahan terjadinya komunikasi tulis peserta didik. 


\section{METODE PENELITIAN}

Sesuai dengan tujuan dari kajian ini, jenis penelitian yang digunakan adalah deskriptif dengan pendekatan kualitatif sehingga peneliti dapat mendeskripsikan kesalahan komunikasi tulis dalam menyelesaikan soal induksi matematika dan mengetahui penyebab melakukan kesalahan. Penelitian kualitatif dimulai dengan memahami gejala yang menjadi perhatian untuk selanjutnya dilakukan cross cek dari berbagai sumber sehingga peneliti merasa puas dan yakin tentang kebenaran informasi yang dikumpulkan (Hardani et al., 2020).

Subjek penelitian ini adalah mahasiswa yang memprogram mata kuliah teori bilangan semester ganjil 2020/2021 yang berjumlah 20 orang. Sesuai dengan rencana pembelajaran semester (RPS) materi induksi matematika merupakan materi pertemuan kedua setelah kontrak perkuliahan. Adapun instrumen yang digunakan dalam penelitian ini adalah tes induksi matematik dengan menggunakan penilaian yang merujuk pada pengkategorian aspek kemampuan komunikasi matematis menurut Firda dkk sebagai berikut:

\section{Tabel 1: Pelevelan Kemampuan Komunikasi Matematis}

\begin{tabular}{|c|c|}
\hline PELEVELAN & KETERANGAN \\
\hline 4 (sangat baik) & $\begin{array}{c}\text { Memenuhi 4 } \\
\text { indikator }\end{array}$ \\
\hline 3 (baik) & $\begin{array}{c}\text { Memenuhi 3 } \\
\text { indikator }\end{array}$ \\
\hline 2 (cukup baik) & $\begin{array}{c}\text { Memenuhi 2 } \\
\text { indikator }\end{array}$ \\
\hline 1 (kurang baik) & $\begin{array}{c}\text { Memenuhi 1 } \\
\text { indikator }\end{array}$ \\
\hline 0 (tidak baik) & $\begin{array}{c}\text { Tidak ada indikator } \\
\text { yang terpenuhi }\end{array}$ \\
\hline
\end{tabular}

\section{HASIL DAN PEMBAHASAN}

Berdasarkan hasil tes induksi matematika diperoleh informasi bahwa dari skala nilai 30 , diperoleh perolehan rata-rata nilai benar 17,7. Jika perolehan tersebut dinyatakan dalam skala 100 perolehan rata- ratanya 59. Adapun perolehan rata-rata kesalahan komunikasi tulis:

Tabel 2: Kesalahan Komunikasi Tulis dalam Menyelesaikan Soal Induksi Matematika

\begin{tabular}{|l|c|}
\hline Aspek Komunikasi & Rata-Rata Kesalahan (\%) \\
\hline $\begin{array}{l}\text { Penggunaan } \\
\text { Bahasa Matematika }\end{array}$ & 30.12 \\
\hline $\begin{array}{l}\text { Strategi Pemecahan } \\
\text { Yang Digunakan }\end{array}$ & 14.46 \\
\hline $\begin{array}{l}\text { Ketepatan Dan } \\
\text { Kebenaran } \\
\text { Jawaban }\end{array}$ & 37.95 \\
\hline Struktur Jawaban & 17.47 \\
\hline
\end{tabular}

Tabel 2 menunjukkan kesalahan komunikasi tulis terletak pada aspek ketepatan dan kebenaran jawaban sebesar $37.95 \%$, diikuti tipe kesalahan penggunaan bahasa 
matematika sebesar $30.12 \%$. Setelah itu kesalahan pada aspek struktur jawaban sebesar $17.47 \%$ dan terakhir kesalahan pada strategi pemecahan yang digunakan sebesar $14.46 \%$. Perolehan ini memberikan informasi bahwa ketika subyek penelitian menyelesaikan soal induksi matematika, subyek cenderung terkendala pada aspek penggunaan bahasa matematika, strategi pemecahan yang digunakan, dan struktur jawaban yang berdampak pada aspek ketepatan dan kebenaran jawaban. Akan tetapi dari ketiga aspek tersebut, dominan subyek penelitian melakukan kesalahan pada aspek penggunaan bahasa matematika. Hal ini terlihat dari cara mahasiswa membuktikan yang belum mengikuti prosedur pembuktian sesuai prinsip induksi matematika. Dengan demikian, yang menjadi faktor penyebab peserta didik melakukan kesalahan komunikasi tulis adalah kurangnya penguasaan konsep induksi matematika dan lemahnya penguasaan pembuktian mengikuti prosedur yang disebabkan ketidaktelitian dalam melakukan perhitungan.

Berikut dipaparkan salah satu contoh penyelesaian soal induksi matematika subyek SW:

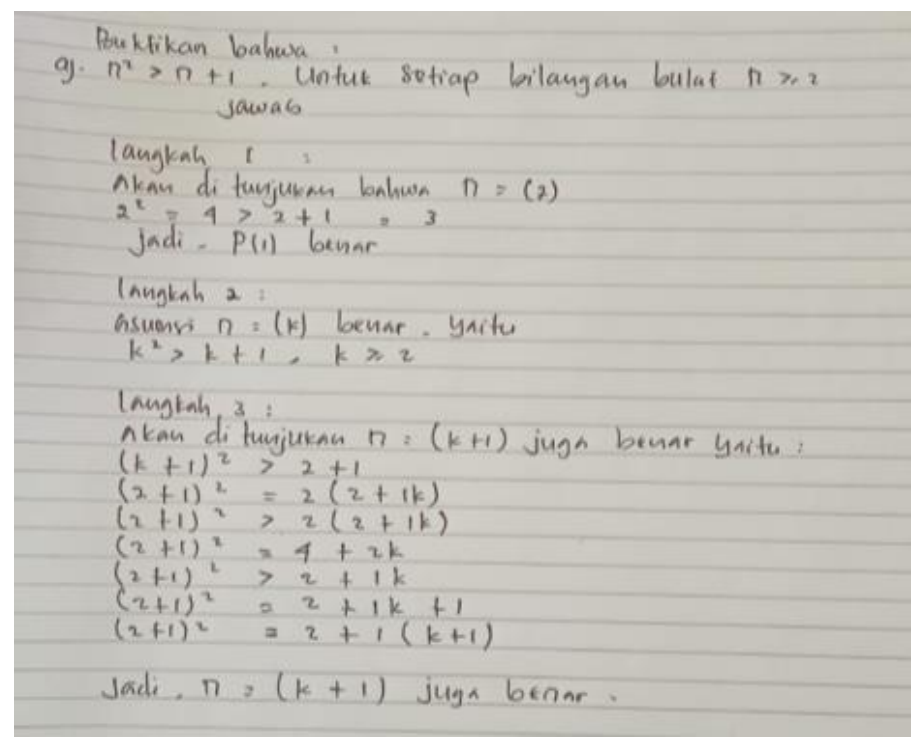

\section{Gambar 2: Jawaban Subyek SW}

Pada jawaban yang diberikan subjek SW terdeteksi melakukan kesalahan komunikasi tulis pada aspek ketepatan dan kebenaran jawaban sebesar 30, kesalahan penggunaan bahasa matematika sebesar 20, sedangkan strategi pemecahan yang digunakan dan struktur jawaban memiliki skor kesalahan masing-masing sebesar 10.

Berdasarkan skor kesalahan tersebut, dapat diketahui bahwa kesalahan komunikasi tulis secara umum masih berada pada 3 level terendah, yaitu dalam kategori cukup baik dengan ciri menunjukkan tahapan penyelesaian masalah tertulis untuk konsep tertentu saja, banyak kesalahan dalam mengubah permasalahan ke bahasa matematika dan dalam perhitungan. Hasil ini menunjukkan bahwa subyek yang minim dalam penerapan bahasa matematika mempengaruhi terjadinya kesalahan komunikasi tulis pada aspek ketepatan dan kebenaran jawaban. Akibatnya dapat berdampak pada tingkat kesalahan komunikasi tulis dalam menyelesaikan soal induksi matematika. Hal ini sejalan dengan pendapat Kroll \& Halaby (dalam Kosko dan Wilkins) bahwa dengan menulis memberikan solusi berupa gambar, kata, dan angka sebagai langkah strategi dalam menyelesaikan soal (Kosko \& Wilkins, 2010). Pendapat ini bermakna bahwa kemampuan dalam komunikasi tulis 
menggambarkan kemampuan dalam menyelesaikan soal sehingga dapat menentukan strategi yang akan digunakan dalam penyelesaiannya.

\section{KESIMPULAN DAN SARAN}

Hasil penelitian ini menyimpulkan bahwa:

1. Perolehan secara deskriptif menunjukkan kesalahan komunikasi tulis pada aspek ketepatan dan kebenaran jawaban sebesar $37.95 \%$, aspek penggunaan bahasa matematika sebesar $30.12 \%$, aspek struktur jawaban sebesar $17.47 \%$, dan aspek strategi pemecahan yang digunakan sebesar $14.46 \%$.

2. Kesalahan pada aspek penggunaan bahasa matematika cenderung berdampak pada aspek ketepatan dan kebenaran jawaban.

3. Faktor penyebab subyek penelitian melakukan kesalahan komunikasi tulis dalam menyelesaikan soal induksi matematika adalah kurangnya penguasaan konsep induksi matematika dan lemahnya penguasaan pembuktian mengikuti prosedur.

\section{DAFTAR PUSTAKA}

Amelia, F., \& Trismawati, M. (2015). Hubungan Antara Kemampuan Komunikasi Lisan Dan Kemampuan Pemahaman Matematis Terhadap Hasil Belajar Matematika. PYTHAGORAS : Jurnal Program Studi Pendidikan Matematika,4(1), 10-20. https://doi. org/http://dx.doi.org/10.333 73/pythagoras.v4i1.564

Ardiawan, Y. (2015). Analisis Kesalahan Mahasiswa dalam Menyelesaikan Soal Induksi Matematika di IKIP PGRI Pontianak. Jurnal Pendidikan Informatika Dan Sains, 4(1), 147-163. https://journal.ikippgriptk.ac.id/index.p hp

Fannies, S. A. (2016). Analisis Kesulitan Menulis Ilmiah Sederhana Siswa Kelas IX SMPN 3 Singosari. Jurnal Cendekia, 10(1), 19-28.

Firda, J., Setiawan, S., \& Randi Pratama Murtikusuma. (2019). Analisis Kemampuan Komunikasi Matematis Siswa Peserta Calistung SMP Negeri 8 Jember. Kadikma, 10(1), 116-125. https://doi.org/https://doi.org/10.19184 /kdma.v10i1.11813

Hardani, Andriani, H., Ustiawaty, J., Utami,

E. F., Istiqomah, R. R., Fardani, R. A., Sukmana, D. J., \& Auliya, N. H. (2020). Metode Penelitian : Kualitatif \& Kuantitatif (Issue March).

Hodiyanto. (2017). Kemampuan Komunikasi Matematis Dalam Pembelajaran

Matematika. AdMathEdu, 7(1), 9-18. https://doi.org/http://dx.doi.org/10.129 28/admathedu.v7i1.7397

Huda, A., Isnarto, \& Erwina, L. (2018). Meningkatkan Kemampuan Pembuktian Induktif Kelas XII SMA N 7 Semarang pada Materi Induksi Matematika Melalui Pembelajaran Model TAI. PRISMA, Prosiding Seminar Nasional Matematika, 1, 12- 17.

Kosko, K. W., \& Wilkins, J. L. M. (2010). Mathematical communication and its relation to the frequency of manipulative use. International Electronic Journal of Mathematics Education, 5(2), 79-90.

Maulyda, M. A., Hidayati, V. R., Erfan, M., Umar, \& Sutisna, D. (2020). Kesalahan Komunikasi Matematis (Tertulis) Siswa Ketika Memahami Soal Cerita. Jurnal Karya Pendidikan Matematika, 7(1), 1-7. https://doi.org/10.26714/jkpm.7.1.2020.1-7 
Nursupiamin, N. (2020). Kemampuan Komunikasi Matematika Mahasiswa Ditinjau Dari Cara Kerja Otak Yang Dominan. Koordinat Jurnal MIPA, 1(1), 11-17. https://doi.org/10.24239/kjpm.v1i1.2

Saptika, Y. A., Rosdiana, F., \& Sariningsih, R. (2018). Analisis Kesalahan Siswa Dalam Menyelesaikan Soal Kemampuan Komunikasi Matematis Pada Materi Bangun Datar. JPMI(Jurnal Pembelajaran Matematika Inovatif), 1(5), 873. https://doi.org/ 10.22460/jpmi.v1i5.p87 3-880 